\title{
Tapetud laps ja lapsetapmine pärimuses sotsiokultuurilisel taustal
}

\section{Aivar Jürgenson}

\section{Sissejuhatus}

Teemaga viis mind kokku uskumuste ring, mis seotud metshaldja/eksitajaga. Puudutasin tapetud lapse motiivistikku põgusalt eksitajat käsitlevas ülevaates (vt Jürgenson 1997), kuid siis määras lähenemisviisi kontekst: tapetud lapsest oli juttu peamiselt lähtudes tema kohati esinevast ja suhteliselt sekundaarsest eksitajafunktsioonist, mille taustaks on kontamineerumine metshaldja traditsiooniga. Siinkohal seame aga tapetud lapse teema otse fookusse.

Laiemalt võttes hõlmab surnud lapse teema rahvapärimuses kujutelmi, mis seotud surnultsündinud, imikuna või väikelapsena surnud või tapetud lastega. Käesolevas käsitluses on teised lapse surma kajastumised välja jäetud ja piirdutud lapse tapmise ehk hukkamise fenomeniga, kuid seegi annab võimaluse edasiseks liigitamiseks, sest rääkida saab nii tapetud lapsest kui lapsetapjast. Eesti pärimuses esineb lapse tapjana valdavalt vallasema. On tekste, milles tegelastena figureerivad nii tapetud lapsed kui nende emad, teistes on fookuses vaid üks kahest tegelaskujust ja teine leiab vaid mainimist või sedagi mitte. Kuna eesti pärimuses pole eriti levinud iseseisvad supranormaalse olendina esineva lapsetapja muistendid, võimaldaks materjali folkloristlik käsitlus keskenduda peamiselt tapetud lapse tegelaskujule. Käesolevas kirjatükis olen aga üritanud anda vaadeldavale nähtusele laiemat tausta, mille tõttu leidsin vajaliku olevat pöörata tähelepanu nähtuse sotsiaalsetele faktoritele ja ühtlasi vaadelda ainest puhtfolkloristlikust pisut erineva pilguga.

Etnoloog huvitub sotsiokultuurilistest kommunikatiivset käitumist eeldavatest elamisvormidest. Kuna iga inimeksistentsi vorm on üldjuhul kommunikatiivne ühiskond (ekstreemsituatsioonid kui midagi erandlikku võib vaatluse alt välja jätta), võib väita, et kommunikatiivne käitumine on ühiskonna struktuuri alus. Kommunikatiivset käitumist juhtivad reeglid avaldavad mõju kultuuri igale komponendile ja vaimukultuur, sh usund pole selles mõttes mingi erand. Kommunikatsiooniühiskonna erinevate ilmingute, tema normide ja nende sanktsioonide uurimisel lõikuvad tihedalt etnoloogi ja folkloristi tegevusväljad.

\section{Etnograafilisest ja kirjanduslikust taustast}

Etnograafilised andmed pakuvad suure valiku näiteid, kuidas traditsionaalsed kultuurid on reguleerinud perekonna suurust. Lastesse suhtumise diapasoon kahe pooluse - väikelapse eest hoolitsemise ja surma aktiivse esilekutsumise - vahel on lai, s.t tuntakse mitmeid vahepealseid astmeid. Eeskujulik loote arengu eest hoolitsemine eeldab raseda head toitmist, tema töökoormuse vähendamist (Mac Cormack 1982: 8; Harris 1989: 113). Sellele vastupidist käitumist - raseda näljutamist, raske tööga koormamist - võiks nimetada kaudseks abordiks. Otseste abordi meetoditena tuntakse mitmeid füüsilisi ja keemilisi mõjutusi. Toetudes uurimusele, mis hõlmas 350 eelindustriaalset ühiskonda, väitis George Devereux, et otsene abort oli "absoluutselt universaalne fenomen" (Devereux 1967: 98, tsit. Harris 1989: 113).

Laialt levinud oli ka imikute ja väikelaste tapmine nii otseste kui kaudsete meetoditega (Harris 1989: 114).

Laste tapmine pole omane üksnes traditsionaalsetele kultuuridele. Erinevatest aegadest ja erinevatest kultuuridest on teateid, kuidas ebasoovitud lastest on püütud vabaneda. On siis tegemist ühiskonnas aktsepteeritud nähtusega, mis toimub legaalselt ja millele ei järgne karistust, või teoga, mille paneb kogukonnapoolseid sanktsioone kartes salaja toime üksikisik, mingites vormides leiab nähtus 
retrospektiivsetes allikates ikkagi kajastamist. Varasema aja suulisele traditsioonile lisanduvad ajaloolisel ajal kirjalikud allikad, mille hulgas näiteks kohtuprotokollid on üheks informatiivsemaks. Käesolevas artiklis keskendume siiski peamiselt rahvaluulelisele materjalile.

Laste tapmise teema kajastub arhetüüpse kujundi või sümbolina maailma rahvaste vaimse pärandi erinevates zhanrides. Lastetapmine või selle oht on mütoloogias tähenduslik, kuuludes sageli eksistentsi piirtähisena kangelase tüübi lahutamatute elementide hulka. Lastetapmise oht on justkui kangelase initsiatsioon, proovikivi, mille kaheks võimalikuks üksteist välistavaks lahendiks on kas haihtumine olematusse või kuulsusrikas tulevik. Lastetapmisest pääsemises kätkeb midagi saatuslikku. See, et pääsemine pole kangelase enda teene, allutab ta saatusele ja teeb temast viimase tööriista, võib teda samas ka õigustada edaspidistes elu keerdkäikudes. Oidipuse õnne ja traagika taga oli karjuse halastus, kui see Laiose käsust üle astudes last kiskjatele ei jätnud, Zeus võlgneb elu emale, kes teda mõrvarliku isa eest varjas. Sellest, kellest oleks võinud saada tuhmuv mälestus roimast, saab nimi paljude põlvkondade suus.

Tuntud mütoloogilistest lapsetapjatest tahaks nimetada hurride Kumarbit ja kreeka Kronost, kes oma lapsi õgisid. Motiivid on mõlema kuju puhul sarnased, ilmselt on tegemist sama põhimüüdi teisenditega erinevates oludes (vt Puhvel 1996: 39). Indra puhul viitavad mõned vihjed lapsetapu katsetele ja isatapule. Rigveeda 4.18.12: "Kes lesestas su ema? Kes tahtis sind tappa (emaihu) peidikus või (lootena) liikumas? Mis jumal oli sulle armuline, kui sa isa jalast haarates hävitasid?" (Puhvel 1996: 60).

Brutaalset lastetapmise tava tunti araabia ühiskonnas, kust selle kaotas alles Muhamed (Holma \& Barthold 1933: 32). Koraani 81. suurast loeme: "... Kui elavalt maetud tütarlastelt küsitakse, miks on nad surmatud." Või 18. suura 33. salmis: "Ära tapa oma lapsi puuduse kartuses."

Mitmes seoses leiame laste tapmise ja sellega ähvardamise motiive Piiblist. Kronosega võrreldav on kuningas Heroodes, julm despoot, kes hirmus võimalike võistlejate ees oma poegi mõrvas. Kolm oma poega laskis ta tappa veel enne surma. Moosese tahtsid tappa egiptlased. Jeesus pääses tema hävitamiseks korraldatud Petlemma lastetapust tänu ilmutusele, mille sai Maarja mees Joosep. Juudi esmasündinute tapmist Egiptuses või laste ohverdamist Moolokile mainitakse tõsiasjadena, kuid ohvrid jäävad anonüümseks. Teisiti on lugu Jefta tütrega, kelle tapmise tõik sai laia kõlapinna ja tegi ta rahva seas tuntud ning armastatud kangelannaks, kellest mälestus põlvest põlve erinevates zhanrides edasi kandus. Sündmus on andnud nime analoogidele maailma folklooris (nn Jefta motiiv).

Üldjuhul on Piibli seisukoht laste tapmisse hukkamõistev, mille ühe seletusena võiks välja tuua jumaliku valiku idee. Nii näiteks olid prohvetid Jeremija ja Ristija Johannes Jumala poolt valitud oma missiooni täitma juba enne sündi.

Eesti suulises traditsioonis esineb laste tapmise teema mitmetes zhanrides: laulutüübid "Tütar vette", "Tütarde tapja", "Vaeslaps käoks", viimasega haakuv muinasjututüüp käo sünnist (AT 720), mitmed muistenditüübid. Kui ballaadid ei manifesteeri ei lapsi ega lapsetapjaid üleloomulikul (kummitaval) kujul ning narratiiv piirdub tapmise fakti konstateerimisega, siis muistendites kajastub tapmise motiiv, üldsuse vastukaja ning lapse ja ta tapja edasine saatus selgemalt. See põhjendab käesoleva artikli rõhuasetuse muistendilisele materjalile.

Kui vaadelda sündi ja surma siirderiitustena, kerkib selgelt fookusesse suhe indiviidi ja sotsiaalse grupi vahel. Siirderiitused fikseerivad ja reguleerivad ülemineku ühest sotsiaalsest staatusest teise. Kogukond kontrollib indiviidi seisundit kahe sotsiaalse identiteedi vahel. Sünd nagu ka surm pole üksnes füsioloogiline fakt, vaid ka sotsiaalne akt (Kitzinger 1982: 181, 182). Kontroll seisneb vastavalt olukorrale kaitses või destruktsioonis. Varasemates kultuurides otsustas kogukond laste 
ellujätmise või tapmise/hülgamise. Laste tapmise motiivid ja õiguslik suhtumine sellesse varieeruvad kultuuriti. Lapse sobivuse määramisel ühiskonda kehtivad maailma erinevates kultuurides erinevad kriteeriumid, millest olulisemad on sugu (kütid-kalastajad eelistavad poeglapsi), defektid (Kesk-Euroopas ei jäetud vigast last küll maha, aga ei aktsepteeritud ka täieõigusliku ühiskonnaliikmena) ning sotsiaalne taust (vallaslapsi sageli ei aktsepteerita). Erinevad on tapmise põhjused: majanduslikud (toidu nappus), religioossed (esmasündinud, kaksikud, hambaga sündinud, vigased), sotsiaalsed (ebaseaduslikud lapsed). Aafrikas on tapetud heleda näoga sündinud lapsed, et nad ei tooks kogukonnale õnnetust (Encyclopaedia... 1971: 16). Ida-Aafrika lumbwadel on tava tappa ebaseaduslikud ja vigased lapsed ja need, kes sünnivad hambaga. Teise Ida-Aafrika rahva, akikuyude liikmed tapavad kaksikutest viimasena ilmaletulnu. Mõnes kultuuris on kaksikute sündi peetud naise abielurikkumise tulemuseks ja märgiks. Sellisel juhul kuulutatakse üks laps legaalseks ja jäetakse ellu, teine hüljatakse. Lõuna-Aafrikas elavad hererod peavad kaksikute sündi heaks märgiks ja jätavad lapsed elama, hotentotid seevastu tapavad mõlemad kaksikud. Mõningates kultuurides, sh Austraalia aborigeenidel, hotentottidel ja Boliivia indiaanlastel, tapetakse laps, kui ema sureb sünnitusel (Pentikäinen 1968: 66). Wotjabaluki hõimu liikmed Edela-Austraalias tapsid sageli vastsündinu, et anda elujõudu vanemale lapsele (Mead 1947: 7). Mitmetes kultuurides teostatakse selektsiooni soo alusel, kusjuures tavaliselt eelistatakse poeglapsi. Kirde-Hindustanis elavad feregad hukkasid suure osa tüdrukutest kohe pärast sündi. Lapsed tapeti oma ema poolt lämmatamise või oopiumiga mürgitamise teel (Encyclopaedia... 1971: 16). Ebasoovitud lapsed hukatakse vaatamata mõne kogukonnaliikme vastuseisule, s.t kogukond otsustab lapse saatuse.

Ühiskonna normatiivjuriidiline käitumine määrab laste (ühiskonna uute liikmete) staatuse. See võib olla tihedalt seotud ka kultuuri vaimse sfääriga, nii selle mõjutajana kui reaktsioonina. Paljudes kultuurides ei käsitata last enne teatava siirderiituse toimetamist kogukonna liikmena. Alles nime andmine, esimene juuste lõikamine, lapse kätele võtmine isa poolt vms ühiskonnas aktsepteeritud rituaal annab lapsele kogukonna liikme ja inimese staatuse. Laps, kellega rituaale ei toimetata, ei kuulu kunagi ühiskonda. Kui lapsele pole antud sotsiaalsust, on ta samas seisundis sellega, kes sureb enne ühendamisriituste toimetamist (Pentikäinen 1968: 61).

"Kalevalas" esinev süzhee Marjattal sündinud pojast ja seda ähvardanud ohust kuulub samasse kategooriasse. Kui kohalekutsutud poistest keegi end lapse isaks ei tunnistanud, tegi kohtunikuks olnud Väinämöinen karmi otsuse: laps tuleb heita sohu. Imekombel sai laps kõnevõime ja kuulutas, et tema isa pole keegi muu kui kohtunik ise. Väinämöinen oli muidugi nii masendatud, et otsustas teise maailma purjetada, kuid meie jaoks on oluline loos ilmnev tavaõiguslik tõik. Vana Skandinaavia kombe kohaselt pandi lapsele mõne esivanema nimi. Kui isa oli tundmatu, ei saadud lapsele ka nime anda ning ta tuli hukata. Laul on teisendina tuntud ka Eestis.

Staatuseta ehk nimetul lapsel pole hinge. Küsimus on siin inkorporeeriva akti ja sellest tulenevalt lapsetapmise normatiiv-juriidilises kaalus. On antropolooge, kelle meelest ei saa emiliselt sellise lapse, s.t ühiskonna poolt aktsepteerimata lapse tapmist käsitada mõrvana (Mead 1947: 7; Harris 1989: 115).

Läänelikus kultuuris on üldtunnustatud initsiatsioonirituaalina, mille tulemusena laps siirdub inimühiskonda, kehtinud ristimine. Samas on ristimist peetud tingimuseks, mis võimaldab hingele elu teispoolsuses. Vana Testamendi värvikas lugu sellest, kuidas juudi kogukond Moosesega eesotsas ja pilve- ning tulesamba juhtimisel läbi Punase mere läks, omandab evangeelses keskkonnas uue mõõtme. Taevariiki ei pääse, olemata sündinud veest ja vaimust (Jh 3:5) - selles on nähtud imperatiivset tingimust. Sümbolikeeles esindavad puhastav vesi ja pimedust peletav põlev küünal hinge taassündi uude ellu (vt ka O'Connor 1991: 17). 
Juriidiline hoiak lapse suhtes, kellega ühiskonda integreerimise riitust pole toimetatud, laieneb teispoolsusele: kui sureb laps, kes ei kuulu ühiskonda, ei ole tal üldkehtiva arusaama kohaselt võimalust liituda ka surnutega. Staatusele vastavad on ka matused: laps maetakse külast välja. Näiteks Celebe saarel Indoneesias surnult sündinu või see, kes sureb 2-3 päeva vanuselt, maetakse ilma kirstuta süvendisse puu tüves ja pitseeritakse. Toimingu eesmärk on preventiivset laadi: takistada kurja tegemist surnud lapse poolt. Sarnane on ka obiugrilaste traditsioon. Kardetakse, et laps, kelle tema ema on matnud kivi või puujuure alla, võib muutuda suuresilmseks ja suure suuga olendiks nimega ütpi. Et takistada sellise olendi väljatulekut, peidavad nad keha õõnsa puu juurte alla, kaevates ta maasse kasetohust korvis ning asetades kivi kõhule või pea peale (Karjalainen 1921: 191-193; Karjalainen 1948: 736; Pentikäinen 1968: 61-62). Probleemi surnultsündinu või tapetud lastega võib lahti mõtestada nii: neile pole antud sotsiaalset staatust selles ilmas, järelikult ei saa nad ka surnute ühiskonda integreeruda, jäädes alatiseks piirile. See annabki neile aktuaalsena kestva tähenduse usundis. Liminaalne positsioon või seisund tähendab elavate maailmale eelkõige seda, et olend, keda see otseselt puudutab, s.t see, kes ei saa lahkuda teise maailma, säilitab kontaktid siinpoolsusega, paikade ja inimestega, kellega ta varemgi, elavana, kontakteerus. Niisiis ei lahku selline surnu päriselt, tuletades end meelde üleloomulike olukordade ja elamuste kaudu. Teda ei saa unustada, mälestused, temaga seotud reaalid ja situatsioonid tuletavad end üha uuesti meelde. Ja teistpidi: teadmine tema olemasolust aktualiseerib varasemad sotsiaalsed ja emotsionaalsed sidemed. Viimaste juriidiline, normatiivse käitumisega seonduv kaal on kohati otsustav.

Vaenulikkust eeldatakse eriti sellelt, kelle suhtes on käitutud ülekohtuselt. Vaime kogetakse empiiriliselt, neid usutakse elavat ja tegutsevat inimese lähimas ümbruses. Nende teed võivad inimeste omadega ristuda ka siis, kui seda ei taheta, kui nendega kontakte ei otsita, s.t kui ei toimetata vaimudele suunatud riitusi.

Haldjaelamusi võib üldjuhul liigitada kaheks. Esiteks enamasti ootamatud, soovimatud kohtumised üleloomuliku olendi või olenditega, kusjuures elamuses domineerivad emotsionaalsed faktorid, tekivad tugevad afektid ebakindluse, hirmu jne näol. Teiselaadsed on haldjariitused, milles otsitakse kontakti üleloomulikuga. Riituste puhul üllatusmoment puudub, domineerivad austus, lootus, ootus, usaldus. Riitused kulmineeruvad harva vaimuilmutustega, tavaliselt jääb haldjas nähtamatuks. Haldjailmutuste kaks eri liiki võivad teatud juhtudel seguneda: inimene näeb haldjat, ehmub ja teostab rituaali - näiteks lööb risti ette (Honko 1962: 89, 111).

Siinkohal käsitletav tapetud lapse teema kätkeb endas sageli haldjaelamuste kaht eri liiki korraga. Kasuaalsele kohtumisele, vahel ehmatavale kontaktile surnud lapsega mitmes muistenditüübis järgnev rituaali teostamine - luude ümbermatmine vms - toimub normi manifestatsioonina. Reeglite rikkumisest tingitud häireseisund, hälbimus rollikäitumisest, parandatakse normidesse naasmisega.

Põhjala surnud lapse traditsioon on valdavalt tapetud lapse traditsioon ning mõneski mõttes kriminaalne: surnud laps tuleb kätte maksma, paljastama tapjat. Läänepoolses Põhjalas taotlevad surnud lapsed ristimist, idapoolses matmist pühitsetud mulda (Pentikäinen 1968). Mõlemad motiivid on eesti pärimuses esindatud. Kui võrrelda eesti traditsiooni Põhjala ja mõne teise Euroopa vastava traditsiooniga - näiteks on iiri materjalile tuginev põhjalik uurimus Anne $\mathrm{O}^{`}$ Connorilt -, siis võib eesti ainest Põhjala traditsiooni kuuluvaks või sellele lähedaseks lugeda.

\section{Tapetud lapse kujutelm Eestis}

Lähemalt on käesolevas artiklis vaatluse all kaks muistenditüüpi: "Hukatud laps nutab" ja teine, mida võiks pealkirjastada "Vanem vend hukatud lapsena", kuivõrd need kajastavad nähtuse sotsiaalset tausta kõige selgemini. Kuna käesoleva artikli ülesanne on eelkõige käsitleda nähtuse ühiskondlikke retseptsioone, pole siinkohal seatud eesmärgiks kogu lapsetapmise tüübistiku 
analüüs. Nähtuse terviklikuma tausta huvides pole teised lapse tapmist kajastavad tüübid vaatluse alt siiski päriselt välja jäetud. Nii näiteks muistenditüüp lapsetappu kavandavast tüdrukust, kes viimasel hetkel oma plaanist loobub, ei kuulu otseselt tapetud lapse motiivistikku, küll aga kajastab ühiskonna hoiakut vallasemade ja -laste suhtes, seetõttu ei saa temast vaikides mööda minna.

\section{"Hukatud laps nutab"}

Mingi eriskummalise, üleloomuliku ilmingu või märgi peale laste luude leidmisest, s.t lapse tapmise avastamisest on hulgaliselt teateid mitmetes variatsioonides. ERA rahvauskumuste kartoteek sisaldab märksõna all "Hukatud laps nutab" hulgaliselt teateid selle kohta, kuidas nutu kuuljad otsides hääle asukohta, leiavad lapse laiba. Tapetud lapse matmiskohana nimetatakse tavaliselt mõnda paika elupaiga lähedal, kuhu tapetud laps on peidetud: kiviaia sisse, ahju, põranda alla, kivi alla, räästa alla, aida trepi alla, aidanurga alla, õunapuu, kirsi vms aiapuu juurte alla, rehte, kraavi jne. Ühe levinuma lokalisatsioonina esineb: rehe taga nõgeste sees. Mitme teate kohaselt on tapetud laps maetud põllule ja metsa, ühes näiteks põllule tamme alla (Narva).

Materjal on struktuurilt siiski suhteliselt homogeenne ja pisut skemaatilinegi, vahel nimetatakse luude/laiba leidmise järel nende matmist pühitsetud mulda, mille järel kummitamine on lakanud, sageli lõpevad aga lood vaid leidmise fakti sedastamisega. Kuritegu on valdavalt anonüümne, kuriteo iseloom jääb enamasti täpsustamata. Sisult liituvad sama tüübiga lood, mille skeem on sarnane, kuid milles lapse laiba või luude leidmisele ei juhata mitte nutu kuulmine, vaid mingi muu märk. Üleloomulikuga kommunikeerumise karakteristika, teated märkide kohta, mille peale luid otsima asutakse, on mitmekesine. Sageli on tegemist visuaalsete märkidega. Ühes teates on juttu valgest linnust, keda nähti öösel müüri sisse lendamas. Päeval müür avati ja leiti lapse luud (H II 57, 92/3 (3) < Kose - T. Viedemann (1897)). Ilmselt on tegemist saksamõjulise laenuga elava inimese sissemüürimise loost. Visuaalsete kuritegu reetvate märkidena esinevad veel vilkuvad tulukesed (H II 57, 389/90 (9) < Tallinn - A. Ploompuu (1896)), kaks sinist saksa (E $9213<$ Tõstamaa - J. Jagusmidt (1894)), ihualasti noor naisterahvas (E 63203/4 (10) < Jämaja - A. Kuldsaar (1928)), koer (ERA II 13, 20/1 (12) < Simuna - R. Viidebaum (1929)). Kui mõnd nimetatud figuuridest võib pidada hingekontseptsiooni kandjaks, siis paljudel juhtudel on see küsitav - luud ja neid avalikustav märk assotsieeruvad mingil muul viisil. Tegemist on peamiselt individuaalsete ja isoleeritud kujutelmadega tapetud lapse traditsioonis.

Üleloomulik ja mõistetamatu leiab seletuse traditsioonis, individuaalset supranormaalset elamust kontrollib kollektiiv, korrigeerides ja tüpologiseerides üksikisiku poolt läbielatu. Vormist lähtudes jagunevad muistenditüübi "Hukatud laps nutab" tekstid kaheks, ajaviitelisteks ja hoiatus- või didaktilisteks muistenditeks. Esimese ülesehituses on esikohal kummalise, ebatavalise sündmuse kirjeldus, millele järgneb seletus, teise puhul on järjekord vastupidine: tekst algab normi rikkumise fakti sedastamisega, millele järgneb seose andmine üleloomulikuga või karistuse kirjeldus. Muistenditüübi "Hukatud laps nutab" ajaviitelise variandi puhul ei saa igas seoses lapse nutu kuulmisest rääkida kui millestki detektorilaadsest, mille abil luid leida võib. Nimetatud muistenditüübi variantides ei järgne lapse nutu kuulmisele vms lapse luude leidmise kirjeldus sajaprotsendilise järjekindlusega, vahel järeldatakse peidetud luude olemasolu a priori nutu kuulmisest à la: küllap annab nutt märku peidetud luudest. Memoraadi kristalliseerumisel muistendiks omandab üksikjuhtum tüübi tunnused ja isegi juhul, kui tüübi elemendid konkreetses variandis täielikult ei kajastu, annab loo ülesehitus tunnistust konkreetsest skeemist.

Teine osa nimetatud temaatikat kandvatest tekstidest on liigendatud vastupidises järjekorras, nn hoiatusmuistendi skeemi järgi: kõigepealt esitatakse info lapse tapmisest (kas kellegi poolt või umbisikuliselt) ja seejärel lisatakse seos üleloomulikuga: selles paigas kummitab, on kuulda lapse 
nuttu vms Memoraadi ja muistendi puhul peab arvestama sellega, et iga järgmise traditsioonikandja esituses võib ta saada uue kompositsiooni, elemendid võivad ümber paikneda ju suhteliselt vabalt, kui edastatav mõte sellest esitaja meelest ei muutu. Kohati ilmneb taoline ümberpööratus ka järgnevalt vaadeldava tüübi puhul.

\section{Muistenditüüp "Vanem vend hukatud lapsena"}

Eesti traditsioonis tuntud vanema venna muistenditüübis esinevatest motiividest on siinkohal olulisim kuriteo, lapse salaja tapmise ilmsikstuleku motiiv, sealt edasi aga süü ja karistuse teema. Lugu ise on selline: mees käib (või sõidab hobuveokiga) üksinda teed ja ühtäkki astub talle juurde (või istub reele/vankrile) võõras, kes tutvustab end mehe vennana. Kui mees üllatunult vastab, et tal venda polegi, avaldab võõras saladuse: mehe emal sündis neiupõlves poeg, kelle ta salaja tappis ja maha mattis. Nüüd ei saavat ta enne rahu, kui ta pühitsetud mulda ümber maetakse. Enamasti - ja see on siinkohal oluline - ühendatakse motiiv karistuse ja kättemaksu teemaga: ümbermatjaks peab olema lapse ema, kes pärast seda, kui peidetud lapse luud on ümber maetud, sureb.

Tasub tähele panna, et tapetud vastsündinu esineb muistendis peamiselt noormehena. Usuti, et liminaalses sfääris toimib aeg samamoodi nagu siinpoolsuseski. Mitmes tekstis ilmneb, et mõrvast möödunud aeg on vastavuses üleloomuliku olendi eaga: üks variant räägib 21-aastasest noormehest ning nendib, et laps tapetigi 21 aastat tagasi (ERA II 159, 615/6(209) < L-Nigula - E. Ennist (1937)), teises räägitakse umbes kahekümneaastasest olendist, kes kontakteerub oma 16-18-aastase noorema vennaga (ERA II 109, 23/4(6) < Ludza - P. Voolaine (1931)). Sirgumine teispoolsuses on ilmne ka enamikus variantides, milles räägitakse väikesest poisist või tüdrukust, kuigi vanus jääb konkretiseerimata. Anne O'Connor täheldab sarnast motiivi iiri muistendites ristimata surnud lapsest. Need esinevad väikeste lastena, kes näivad olevat kasvanud suuremaks kui vastsündinu. Usk, et surnud lapsed jätkavad kasvamist teispoolsuses, on leidnud kajastamist tavas eemaldada surnud lapse kirstul otsalaud, hõlbustamaks tema edasist kasvamist (O'Connor 1991: 66, 117).

Eesti pärimuses esineva vanema venna tüübi elementides on varieerumisi, kuid alati on tapetud laps temaga kohtujaga sugulusvahekorras: paaris tekstis pole surnud lapseks mitte vanem vend, vaid õepoeg (H I 2, 203 (1) < Põltsamaa - J. Raavel (1889); S 61352/6 (9) < Setu, Mäe v. - N. Sõrmus (1933)), noorem vend (H II 39, 1001/3 (957) < Koeru (1892)), ühes loos kaks tapetud venda korraga (H III 25, 714/5 < Suure-Jaani - T. Kuresson (1896)), isa kohtav poeg (kusjuures isa mõrvast ei tea) (E 15353/5 < Narva - J. Karukehv (1895)).

Eriti tugev näib olevat varieeruvus mõningates elementides Setumaal. Vanema venna asemel esineb üleloomuliku olendina tihti õepoeg, aga sage on nimetatud lugudes ka seos kuradiga. Lokaaltraditsiooni olemasolust Setus kõneleb ilmselt ka teade, milles lapse tapnud emale saadetakse korraldus: ta küpsetagu leib ja pangu sinna, kuhu ta lapse mattis. Ka siin järgneb rituaali teostamisele ema karistamine: emal hakkas seepeale suust nõnast vatto ajama (ERA II 163, 153/4 (13a) < Setu, Vilo V. - N. Ress (1937)).

Kokkupuutes üleloomulikuga, sh haldjaelamuse puhul - tavaliselt on tegu lühiajalise episoodiga mõjutavad inimese taju sageli emotsionaalsed faktorid, mis on osalt tingitud olukorra erakordsusest ja ootamatusest. On siiski küsitav, kas igas seoses seletab olukorra ootamatus iseäraliku tunde. Vahel tajutakse, et teel vastutulev inimene pole õige, ei kuulu tavaliste inimeste hulka, kuigi visuaalsed andmed seda tunnet ei põhjenda. Vahel registreeritakse ajanihe, näiteks avastatakse pärast kontakti üleloomuliku olendiga, et möödunud on tunduvalt pikem ajalõik, kui esialgu paistis. Supranormaalsele kogemusele viitab tähelepanek mitmetes vanema venna muistenditüübi variantides, milles siis, kui tapetud laps hobuveokile istub, muutub selle kiirus, tavaliselt aeglasemaks, (põhjendatakse sellega, et hobusel on raske vedada), mõnes tekstis ka kiiremaks. 


\section{Piiriloleku fenomenist surnud lapse traditsiooni puhul}

Oluline mõiste, mis esineb nii katoliku kiriku õpetuses kui paljude rahvaste usundis, on liminaalsus. Kiriklik seisukoht surnud lapse suhtes on aegade jooksul olnud erinev, muutudes ja arenedes kirikuisade ja teoloogide õpetuste mõjul. Pelagiuse meelest võisid ristimata surnud imikud siseneda "igavesse ellu", kuid mitte "Jumalariiki". Selle seisukoha vaidlustas Augustinus. Toetudes ristimise vajalikkusele, mida näib postuleerivat Jh 3: 4, paigutas ta selliste laste asukoha põrgusse, milles ta nägi ainsat alternatiivi. Leebema seisukoha järgi, mida toetasid Kreeka kirikuisad neljandal sajandil, iseäranis Gregorios Nysses, lähevad ristimata laste hinged vahepealsesse maailma. Mõtet arendasid edasi 12. sajandil skolastikud. Palju on vaieldud selle üle, kes kasutas esimesena mõistet Limbus Puerorum või Limbo (omistatud on seda Albert Suurele (1280) ja Peter Lombardi kommentaatorile (1322)), igal juhul tuleneb väljend ladinakeelsest sõnast limbus (piir, äär, serv). Aquino Thomas läks kaugemale ja formuleeris oma teostes seisukoha, milles tema kontseptsioon looduslikust ja mittepersonaalsest pärispatust vastandub selgelt õpetusele, mille kohaselt ristimata imikud peavad kannatama the pain of sense, vaid nad on pigem määratud elanikeks teise, vahepealsesse maailma, kus nad kannatavad kaotusepiina (the pain of lors). Thomase seisukohast sai katoliku kiriku õpetuse doktriin. See leiab kasutamist ka tolleaegses kirjanduses. Nii näiteks on Dante "Jumalikus komöödias" Limbo postuleeritud kui pime ja rõõmutu paik. Sellisena levis keskaegses Euroopas ettekujutus Limbost, kuid päriselt ei tõrjutud välja ka varasemat Augustinuse koolkonna teooriat (O'Connor 1991: 18-19). Edasised sajandid tõid kaasa uusi vaidlusi, mis paisusid vahel tõsisteks lahkhelideks kiriklikes ringkondades. Ühtse kiriku lagunemine reformatsiooni tulemusena hägustas pilti veelgi. Mil määral mõjutasid rahvausundi kujutelmi teoloogilised elitaarsed mõttearendused, on vaieldav. Seisukohtade variaablus, mis iseloomustab õpetlaste kujundatud klerikaalset lähenemisviisi antud küsimuses, omab teatavaid ühisjooni rahvalike kujutelmadega. Meie käsutuses olevas muistendilises materjalis peegeldub samuti teatav vaadete pluralism.

Ettekujutus liminaalsetest surnutest on andnud alust erinevate kujutelmade tekkele. Kohati usuti, et tapetud lapsed seni kodus käivad, kui neile jumalast antud elupäevad maa pääl otsa saavad, või mõni nad lunastab (ERA II 7, 676 (2) < T-Maarja - E. Treu (1928)). Kohati vastab ettekujutus liminaalsusest klassikalisele katoliiklikule õpetusele: ühes vanema venna muistenditüübi variandis räägitakse tapetud lapsest: "Ei taheta teda ega teisi temasuguseid taeva ega põrgu (E 12336/8 (3) < Ambla - Ehrmann (1894)). Rehes tantsivate neidude loos räägib nõelaga tabatud neiu:

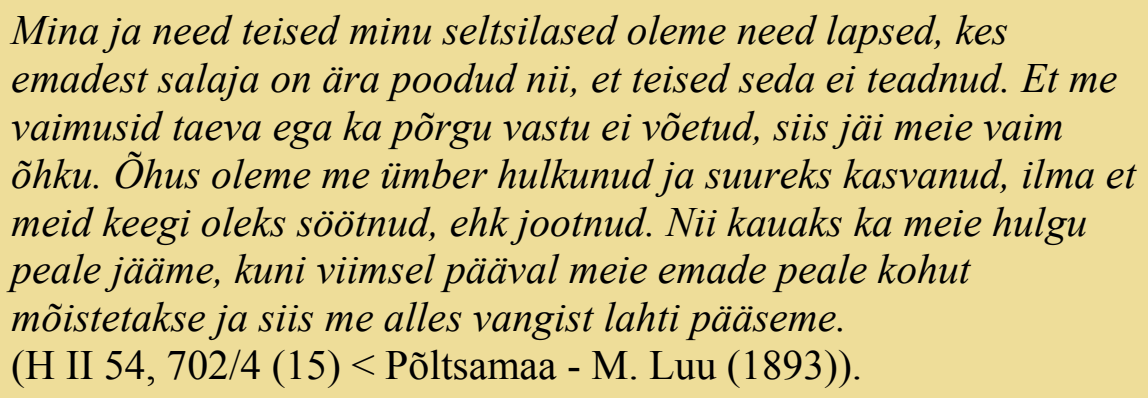

Igatahes pole polaarne põrgu-taevas-jaotus surnud lapse teema puhul eriti levinud. Olen leidnud vaid paar teadet, milles väidetakse, et tapetud lapse hinge pärib kurat (E, StK 34 (32) < Kursi - P. Berg (1926); ERA II 7, 476 (13) < ̈̈ksi - E. Treu (1928)). Ühes setu tekstis teatab surnud laps vennale oma lugu jutustades: "...kon' i so'oni aoni olli vanahalva käeh (ERA II 117, 58/9 (3) < Setu, 
Vilo v. - J. Orusaar (1935)), kuna aga tekstist nähtub, et mõeldud pole igavikulist põrgut, kajastab seegi teade ilmselt ajutist liminaalset olukorda, milles tapetud lapsel tuleb staatuse puudumise tõttu viibida.

Liminaalsus, mis usutavasti seostub teadvuses lõpetamatusega, kätkeb endas potentsiaali, mis tingibki rituaali teostamise: inimeste süül kahe maailma vahel hulkuva hinge saatus pole lõplikult fikseerunud, tema päästmine inimeste rituaalse, norme manifesteeriva käitumisega on võimalik ja vajalik. Ühtaegu omandab hoiatus - kui rikud norme, siis saad karistada - rituaalse käitumise läbi tugeva kinnituse, mis tugevdab normi väärtust ühiskonnas. Niisiis esineb surnud laps, normi supranormaalne kinnitus, normi sanktsioonina.

Euroopa traditsioonis on keskseks põhjuseks, miks surnud lapse eksistents jätkub teises ilmas liminaalses sfääris, ristimise puudumine (O'Connor 1991: 98). Eesti materjal ei näi selle poolest erinevat, mida kinnitab tõsiasi, et tapetud lapse vabastamiseks needusest on uskumuste kohaselt üldjuhul vajalik kristlik pühitsus: ümbermatmine, palve, pühitsetud pinnas (ristitud muld), luude ristimine, neile nime andmine ja surnuaeda matmine.

\section{Karistusest ja pühitsusest}

Eshatoloogilised teemad hõlmavad niisiis liminaalsete hingede saatust, milles oluline karistuse motiiv. Vanema venna loos kaasneb vendade kohtumisega tavaliselt ema kui süüdlase avalikustamine ja surm, s.t kättemaksu motiiv on tugev. Tavaliselt järgneb tapja (tavaliselt ema) surm ümbermatmise rituaalile. Tüübi piires kohtame siiski variatsioone. Selles mõttes on huvitav järgmine lugu: Noormees võttis naiseks teise mehe last ootava tüdruku. Tüdruk tappis salaja lapse ära. Kord, kui mees metsas kündis, nägi ta poisikest, kes ütles: "Ma oota hindäle asemiku." Noormees läks koju ja leidis naise pooduna (H II 51, 791 (2) < Oudova - J. Tamm (1894)). Ühes teates teostas ümbermatmise vend, aga ema toas ikkagi suri (H III 25, 714/5 < Suure-Jaani - T. Kuresson (1896)). Ühes variandis läheb tapetud laps ise (esineb suurt kasvu mehena) koju ema tapma (H III 25, 716/7 $<$ Suure-Jaani - T. Kuresson (1896)), teises sureb orvud tapnud külamutt pärast seda, kui talle on ilmunud laste ema vaim (ERA II 110, 256 (10) < Kuusalu - I. Piibeman (1935)).

On paar teadet, milles ainuüksi kuriteo avalikustamine toob kaasa ema surma (E 3318/21 < Paistu J. Leppik; E $42111 / 2$ (19) < Rõuge - O. Leegen (1901)). Materiaalse kontakti loomine ema ja surnud lapse vahel mõjub emale hukutavalt: ema sureb või minestab, kui näeb surnud lapse poolt antud rätikut (see, millega ta lapse kägistas) (E 15353/5 < Narva - J. Karukehv (1895); ERA II 61, 344/5 (5) < Lutsi - P. Voolaine (1933)), ühes teates saadab tapetud laps emale viina ja kui see joob, siis sureb (E, StK 34 (32) < Kursi - P. Berg (1926)). Tavaliselt sureb ema pärast lapse ümbermatmist. On hämmastav, millise järjekindlusega esineb vaadeldava tüübi puhul kuriteo eest kättemaksmise motiiv, samal ajal kui muud motiivid, sh tegelaskujude sekundaarsed funktsioonid, varieeruvad üsna tugevalt.

Kättemaksu ja pühitsuse rituaali puhul on tegemist kahe, esmapilgul erinevat iseloomu omava motiiviga. Kättemaksus võib näha seost tavaõigusliku silm-silma-vastu-printsiibiga, kajastades asendava ohvri tingimust: laps ei vabane enne, kui süüdlane on tema kohale asunud. ${ }_{1}$ (Sakraalses) pühitsuses kui siirderiituses avaldub ettekujutus piirilolekust: ümbermatmise, ristimise, nimepaneku põhjuseks on vajadus anda Limbus Puerorumile inimese staatus (nt: ERA II 62, 151/2(28) < LNigula - R. Põldmäe (1933)). Kui nõustuda, et ka asendus (antud juhul valdavalt karistuse kujul) viitab piirilolekule, ajutisusele, siis ilmneb, et mõlemad käsitletavad motiivid lähtuvad tegelikult samast eeldusest, piirilolekust ja staatuse muutmise nõudest. 
Nähtub, et lapse staatuse muutmiseks on vajalik ema surm - seda võiks nimetada staatuste osaliseks vahetuseks. Täielik staatuste vahetus ilmneb aga tekstides, milles pärast rituaali teostamist (ERA II 109, 23/4 (6) < Ludza - P. Voolaine (1931); ERA II 117, 58/9 (3) < Setu, Vilo v. - J. Orusaar (1935)) eeldatakse lapse elluärkamist, vrd muinasjututüüp AT 720, milles poeg muutub linnust taas poisiks, kui on ema surma põhjustanud.

Kristliku pühitsuse taga võib kohati aimata mingit (võib-olla) vanemat rituaali, millel usuti olevat puhastav ja pühitsuslik mõju. Ühes variandis annab tapetud laps emale venna kaudu korraldused: ema peab kolm korda leivalabidaga kontide pealt aida nurga alt mulda tõstma, siis saab laps rahu. Ema tõstiski ja kolmandal korral kukkus surnult maha (H II 39, 1001/3 (957) < Koeru (1892)). Küllap seostub sellega mingil viisil eeltoodud teade Setust (leiva panekust tapetud lapse hauale). Matjaks on kirjeldatud lugudes peamiselt lapse ema, vahel ka see, kellega surnud laps kontakteerus, s.t peamiselt vend, üksikteates esineb matjana õpetaja (E 39149/50< Tallinn - J. Keller (1899)), mis ehk kõige selgemini väljendab kristliku matuse vajalikkust.

Tapetud lapse traditsioonis esineb tekste, milles on toimunud üleminek kummitusest paiga kohahaldjaks, kusjuures ei selgu täpselt seos ilmuva üleloomuliku olendi (haldja) ja surnud lapse vahel (H I 378/9 (4) < Risti - J. Holts (1889)), selged pole haldja funktsioonid. Samas on tekste, milles surnud lapse muutumine haldjaks (peamiselt metshaldjaks) on funktsionaalset laadi, surnud laps on omandanud metshaldja käitumismallid ja iseloomu. Näiteks ajab ta tee peale magama jäänu üles või eksitab metsas ringikolajat. Küsitava algupäraga on järgmine lugu, milles surnud laps (tekstist ei ilmne, et tapetud) muutub metsas poolinimeseks-poolhundiks, teistele huntidele karjaseks (H II 28, 226/7 (5) < ̈̈ksi - K. Blaubrik (1889)).

Tuleb rõhutada, et tapetud lapse teema puhul on peamiseks - vähemalt eesti traditsioonis - staatuse muutmise ja sellega sageli seonduva kättemaksu motiiv, kõik teised motiivid (eksitamine, ristteele magama jäämine, umbluu jne) on vaadeldavad sekundaarset laadi funktsionaalsete adaptatsioonidena, mis pole traditsioonile elulise tähtsusega.

Staatuse muutmise raamistik ilmneb ka muistenditüübis, milles tapetud laste hinged käivad (harilikult) rehes tantsimas, tavaliselt ilusate tütarlastena. Neid tuleb nõelaga, millel õlekõrs taga, visata või heita neile rist kaela, mille järel tantsija seisma jääb ja oma loo ära räägib, s.t paljastab vana saladusse jäänud kuritöö. Õpetaja õnnistab last, misjärel kummitus kaob (H I 2, 207/8 (5) < Põltsamaa - J. Raavel (1889); H II 54, 702/4 (15) < Põltsamaa - M. Luu (1893)). Näeme, et surnud lapse motiveeritus ei ilmne siin nii selgelt kui eelmise, vanema venna tüübi puhul: võrreldes sellega esineb kummitus siin passiivsemana. Vaimupoolne staatuse muutmise soov jääb sõnades lahti seletamata. Arvestada ei saa ka üksikteatega Kursist (selles kutsub rehes ilmuv surnud laps esile ema surma (E, StK 34 (32) < Kursi - P. Berg (1926)), sest sisuline kontaminatsioon vanema venna tüübiga on ilmne.

On täheldatav kahe motivatsiooni kausaalne järgnevus, mis käivitab toimingute ahela: surnud laps ootab kuriteo avalikustamist ja hakkab sel põhjusel kummitama, millele järgnebki inimeste tegutsemine sooviga kummitusest vabaneda. Sama mehhanism ilmneb ka muistenditüübis "Hukatud laps nutab". Iseloomulikud on nimetatud motiivid paaris redaktsioonis, milles tüdruk tapab lapse ja peidab laiba lakka linade alla. See hakkab kummitama. Kummitus kaob, kui tüdruk (politseile) üles antakse ja vangi pannakse (ERA II 125, 47/8 (18) < Jõhvi - M. Tarum (1936); ERA II 125, 512 (244) < Vaivara - L. Kraavik (1936)). Kättemaksu motiiv on ilmne. 


\section{Lapsetapmine patriarhaalse ühiskonnakorralduse peeglis}

Eelnevatest näidetest ilmneb ema oluline roll tapetud last käsitlevates muistenditüüpides, kusjuures ema esineb lapse tapjana. Vahel rõhutatakse, et surnud laps hakkab just ema kummitama (ERA II 125, 514 (253) < Vaivara - L. Kraavik (1936)). Domineerivalt räägitakse ema karistamisest: surnud laps kummitab ema, põhjustab ema surma, mõnes variandis arreteerimise vms.

Tekib seega küsimus, milline on rahvapärimuses lapsetapja edasine saatus loomulikul/üleloomulikul skaalal. Muistendeid, milles lapsetapja manifesteeruks üleloomulikul kujul, pole palju ning olemasolevad liituvad peamiselt muude levinud kummituslugude motiividega. Näib, et valdavalt lõpeb eesti traditsioonis huvi ema isiku vastu tema surmaga, kohati ka sedastamisega, et ta lapse asemel matmispaiga kohahaldjaks saab (nt S 61352/6 (9) < Setu, Mäe v. - N. Sõrmus (1933)). Mõnes tekstis lisatakse, et kurat ta hinge pärib, aga see on ka kõik. Kummitava lapsetapja muistendite rohkusega eesti folkloor kiidelda ei saa. Kummitav ema, kes soovib oma tapetud lapse ümbermatmist surnuaiale, esineb ühes variandis valge kummitava naisterahvana (E, StK 24, 153 (7) $<$ Pühalepa - A. V. Kõrv (1924), teises pisikese noore tüdrukuna (ERA II 8, 425/32< Kärla - M. Tooms (1928)). Leidub üks muistenditüüp, milles noorele kirikuõpetajale ilmub endise kirikuõpetaja vaim koos oma tapetud laste vaimudega. Kui ahju suu alt leitud laste luud kiriklikult maha maetakse, kummitus kaob (H II 53, 679/80 (25) < Simuna - V. Rosenstrauch (1896)). Kui võime pidada seda lugu üleloomuliku lapsetapja looks, siis on ta erandlik sellegi tõttu, et tegemist on isa, mitte emaga. Ühes tekstis on lapsetapjatest emade perspektiiv siiski visandatud: Nii kauaks ka meie hulgu peale jääme, kuni viimsel pääval meie emade peale kohut mõistetakse ja siis me alles vangist lahti pääseme (H II 54, 702/4 (15) < Põltsamaa - M. Luu (1893)).

Järgnevas mitmes teisendis esineva muistenditüübi puhul võiks oletada teatavat seost üleloomuliku lapsetapjaga, kuid assotsiatsioonid on siin ilmselt siiski petlikud, s.t kummitav noor naine on ikkagi surnud laps ise:

Ühes üksikus saunas, kus kedagi ei elanud, on mitu ööd järjestiku
tulukest vilkuma nähtud. Keegi põle julgenud sisse minna lugu
lähemalt järele vaatama, ja nõnda vältanud viirastus kaunis kaua.
Viimaks ommeti on üks mees julgust võtnud sisse minna. Ta
pannud eneselle märja koti pähe ja läinud sauna. Üks poolalasti
naesterahvas tulnud talle vasta ja öölnud: "See on väga hea, et sa
tulid mind mo vaevast peastma: iga neljasaja aasta taka on mul
luba nähtavale tulla: põleks sa nüüd tulnud, siis oleksin ma jälle
pidanud nii kaua vaevlema."
Nüidanud ise küündlaga tuld, ja käskinud meest ühte põrandakivi
ülesse tõsta, mida se ka teinud. Aga nõnda pea, kui kivi alt
sündinud lapse luukere paistnud, kadunud naesterahvas nagu tina
tuhka põranda sisse ära. Teine päev võtnud mees kondid, ja
matnud ristitud maa sisse maha ja sestsaadik põle keegi enam seal
midagi näinud.
(H II 57, $389 / 90$ (9) < Tallinn - A. Ploompuu (1896)).

Kindlasti ilmneb identsus kummitava noore alasti naisterahva ja tapetud lapse vahel variandis, mille leiab numbri alt E 63203/4 (10) < Jämaja - A. Kuldsaar (1928). Niisiis, kuigi lapsetapjast ema on 
muistenditekstides sageli oluline figuur, pole tema esinemine üleloomuliku uskumusobjektina levinud.

On iseloomulik, et valdavalt süüdistatakse laste surmamises emasid, mitte aga isasid või teisi sugulasi. Eks kajastu see selgelt ja ühemõtteliselt ka vaadeldud eesti pärimuses. Paljudel rahvastel on uskumus, et emad, kes on oma lapse tapnud, ja mõrvarid heidetakse paradiisist (või ülailmast) välja. Sotsiaal-juriidilises plaanis peituvad selle taga meeste maailma mängureeglid. Patriarhaalses ühiskonnas otsustab mees, et üks või teine laps ei sobi ühiskonda. Meenutame vastava tava kajastust "Kalevala" loos Väinämöise ja Marjattaga. Kui selgub, et süüdlane on Väinämöinen ise, rändab ta ära. Küllap ei tasu lahkumist tõlgendada endapagendamisena, pigem on põhjuseks isiklik solvumine. Meeste tehtud seaduste vastu eksimise puhul leitakse süüdlane sageli vastassugupoole esindajate seast, hea näide esineb ka Vanas Testamendis. Kui Juuda kuulis, et ta minia Taamar oli hooratööst käima peale saanud, oli ta reaktsioon ühene: "Tooge ta välja, et ta põletataks!" (1Ms 38: 24). Vastuvaidlematud tõendid aga viitasid sellele, et mees, kellest Taamar käima peale sai, oli Juuda ise. Auväärne patriarh teatas seepeale suuremeelselt: "Tema on õigem mind!" (1Ms 38: 26)

Mehejärgse võimu kajastusi võib näha ka laulus "Tütar vette", kus vend käsib tüdruku uputada, mida ema käsku täites teebki. Mehe otsustusõigus ühiskonna struktuuride üle hõlmas nii külakogukonna kui perekonna tasandit. Muistendites kajastuv karistuse teema puudutab aga teo otsest täideviijat, s.t naist, ema. Külaühiskond tsenseeris kehtivaid käitumisnorme ja sanktsioneeris nende alusel üleastujaid. Abieluväliste laste sünd, mis paljastas eksimise normatiivsete käitumisreeglite vastu, pälvis üldise hukkamõistu. Naised ja tüdrukud, kes püüdsid häbist pääseda ja salaja oma lapsed tapsid, olid kahe tule vahel: ühelt poolt ähvardas neid kuriteo ilmsikstuleku korral ühiskonna hukkamõist ja karistus, teisalt rõhus saladuses hoitud süükoorma raskus.

Valiku tegemine oli raske, aga siiski võimalik, mida kajastab ka eesti pärimus: kui peamiselt on vastava teema puhul juttu peamiselt tüdrukutest, kes oma lapsed tapsid ning sellega üleloomulikult toimiva protsessi käivitasid, siis vastupidise näitena olgu nimetatud muistenditüüp, milles tüdruk küll kavatseb oma salaja sünnitatud vallaslast hukata, kuid jätab selle siiski kas kaastundest (laps on ilus) või automaatselt teostatud rituaali tõttu (laps aevastab, mispeale ema ütleb "Aitäh Jeesukesele!") või lapse tapmise eel loetud meieisa palve tõttu (teeb tapmise emale vastuvõetamatuks) tegemata.

Peab tunnistama, et eesti tapetud lapse pärimus on üsna sünge värvinguga. Sellest tuleneb ka tapetud lapse kättemaksuhimulisus. Kättemaksumotiiv, mis kordub loost loosse, toob esile muinasjutuliku didaktika sellest, kuidas kurjus saab teenitud karistuse.

Nii on meil tapetud lapse muistendite puhul tegemist terve hulga eetiliste ja teoloogiliste ideedega, mis omavahel segunevad ja üksteist kohati põhjendavad. Ema isiklik vastutus uue elu hoidmisel esineb kõrvuti vajadusega anda lapsele sotsiaalne staatus, aga ka vajadusega vabastada tapetud laps liminaalsest olukorrast rituaalide täitmise teel. Vanema venna tüübi puhul on kättemaksumotiiv domineeriv, sakramentide vajadust rõhutatakse tavaliselt vaid seoses kuriteo ja karistusega. Nii on pühitseva rituaali teostamise motiiv, mis olemuslikult ehk primaarne, sõna otseses mõttes verega üle valatud. Lääne-Euroopa, sh iiri varasemates surnud (s.t mitte alati tapetud) lapse muistendites kohati tajutavat medievaalset aktsenti (vt O'Connor 1991), vagajutulikku kõrvalmaiku, eesti materjal peaaegu ei kajasta. Eesti tapetud lapse pärimus on pärimus tapmisest ja needusest, karistusest ja kättemaksust. 


\section{Tapetud laps normi sanktsioonina}

On väidetud, et lapsetapmist ei peetud varasemal ajal mõrvaks, kuna lapsele, kes kas oma füüsiliste puuduste tõttu või muudel, kultuurist tulenevatel põhjustel, ei vastanud kehtivatele normidele, s.t kes oli ebasoovitud, ei antud inimese sotsiaalset staatust. See mitmete etnoloogide väide laste tapmise kohta leiaks põhjenduse juhul, kui tõestataks, et sündinud last ei käsitatud oma liigikaaslasena. Liigikaaslase elu üle otsustamine on moraalne otsustus. Elu mõistel on kõige tugevam kaal liigisiseselt. Aukartus elu ees pole keskne mitte üksnes Albert Schweitzeri eetikas. On usutav, et moraalse otsustamise printsiibid võivad sageli olla dikteeritud konkreetsete miljöömõjurite poolt, olla lähtunud utilitaarsuse põhimõttest. Kohandumine, käitumise sobitamine olukorrale või tingimustele vastavaks, on suuresti sunnitud käitumine, mis eeldab kompromisse. Ka lapsetapmisega seotud tõrjemaagilised võtted ja muud etnograafilised andmed viitavad teatud psühholoogilisele barjäärile, vastuolulistele reaktsioonidele lapsetapmise ja tapetud laste suhtes, mis omakorda näib tunnistust andvat kui mitte selgelt teadvustatud, siis vähemalt alateadlikust hirmust liigisisese käitumise hälbega seoses. Kuivõrd liigisisene käitumine on moraalne käitumine, on lapsetapmine alati moraalne otsustus. Kui ka eitada kultuurinähtuste jaotumist loomulikeks-loomuvastasteks ning eirata üldinimlike eetikanormide või käitumisviiside $*_{2}^{2}$ olemasolu ja objektiivset kehtivust valikuliselt selekteeritud etnograafilised andmed võimaldavad ju igasuguseid ekstreemnähtusi normaalseteks ja respekteeritavateks nimetada -, siis primaatide liigisiseste bioloogiliste instinktide olemasolus kahelda ometi ei saa. (Küsimus on niisiis selles, kas see, mida me nimetame kultuursuseks, tuleneb alati kultuurist, kas ta on alati omandatud, kas teda saab seletada üksnes grupi survega üksikindiviidile.)

Võib olendi ilma jätta juriidilisest või sotsiaalsest inimese staatusest, anatoomilist ei saa keegi ära võtta. Ajaloolisel ajal, iseäranis teise aastatuhande lõpul, saab see vastuolu peamiseks põhjuseks lastetapmisse erisuunaliselt suhtumisel (sellest allpool).

Iga järjepidevust taotleva kultuuri eeltingimus on käsitada lapsi sotsiaalsete olenditena ja luua neile soodsad arengutingimused. Agraarses külaühiskonnas tagab järeltulev põlvkond nii majandusliku kui kultuurilise järjepidevuse. Nii bioloogiline kui sotsiaalmajanduslik soodumus determineerivad normatiivse käitumise, interaktsiooni, mis loob tingimused edasikestmiseks ja millest hälbimine sisemiste konfliktideta pole võimalik. Traditsioon annab käitumiseks selged juhised. Vastuollu edasikestmist garanteerivate reeglitega võib sattuda nii üksikisiku kui kogukonna tasandil, kusjuures üks on teisega seotud: on selge, et sisemiste konfliktideta on lapse tapmine üksikisiku poolt teoreetiliselt ehk võimalik vaid ühiskonnas, mis on lastetapmise legaliseerinud. Teisest küljest võib sellise ühiskonna enda eluiga lühikeseks jääda. Mbayadel (Brasiilia) naine tappis kõik oma lapsed, väljaarvatud viimane. Kui sündis uus laps, tapeti eelmine ära. Kuna mbayad ei praktiseerinud ka näiteks võõraste laste adopteerimist, nagu see mõnes teises kultuuris sarnases situatsioonis tavaks oli, pole imestada, et see rahvas välja suri. Laste tapmise praktiseerimise tõttu on välja suremas netslik-eskimod (vt Pentikäinen 1968: 63).

Traditsionaalsetes kultuurides opereerib inimene pidevalt seal kehtivate stereotüüpidega, arvestab üldtunnustatud autoriteetidega, s.t korraldab oma käitumise normidele vastavaks. Põhiväärtuste tagamine ühiskonnas toimub sotsiaalse kontrolli kaudu normide ja neid kindlustavate sanktsioonide abil. Teadmine, et normide vastu eksimine toob kaasa karistuse, kujundab ühiskonna üksikliikme ilmavaate pisimate detailideni. Tapetud laps üleloomuliku olendina, ühtaegu normide rikkumise tagajärg ja karistus, on hea näide traditsiooni normatiivse käitumise väärtustamisest suulises traditsioonis.

Me ei tea, millisesse aega ulatub tagasi eesti pärimus tapetud lapsest sellisena, nagu ta kajastub muistenditüübis vanemast vennast. Oleks kerge paigutada tema teke aega, mil olid maksvusele 
pääsenud kristliku ideoloogia väärtused, ning väita, et temataoline üleloomulik olend valvab kristlike normide järgimist, s.t esineb kristlike normide sanktsioonina ja kajastab muutunud ideoloogilisi tingimusi. Nähtus viitab usutavasti siiski varasemale ajale ja peegeldab konflikte üksikisiku ja kogukonna vahel. Kaugemaleulatuvad järeldused jäägu siiski tegemata, kasvõi seetõttu, et eestlaste eelkristliku tavaõiguse kohta on meie teadmised puudulikud. Majanduse ja sotsiaalelu seoste üksiktahud, suhtumine näiteks vallasemadesse, vallaslastesse jne ei luba otsustada küsimuse üle, mil määral võis surnud lapse traditsioon kajastada konflikte kogukonna autoritaarsuse (hilisemal ajal tõukas laste tapmisele sageli kogukonna hukkamõistev hoiak abieluväliste seksuaalsuhete ja laste suhtes) - ja liigisiseste väärtuste, antud juhul ematunnete vahel. Meenutame muistenditüüpi surmale määratud imikust, kelle ema viimasel hetkel siiski otsustab ellu jätta.

Agraarühiskonnas aktsepteeritud normiks on tugev ja elujõuline ühiskonna poolt tunnustatud perekond, järelkasvu eest hoolitsemine ja laste kindlustamine eluks vajalikuga. Kui keegi ühiskonna liikmetest oma lapse tapab, aktualiseerub üleloomulik olend, kes oma olemasoluga näitab, et laste tapmine on kuritegu. Tapetud lapse matmispaik assotsieerub üleloomuliku ja tihtipeale inimesele vaenuliku või vähemalt häiriva sfääriga. Tapmis- või matmispaiga lähedal nähakse ja kuuldakse eriskummalist, mida seletatakse surnud lapse kummitamisega. Nt: Salaja maetud värdja haua peal ei saa magada; hääl ajab minema... (RKM II 170; 324/5 (15) < Pöide - O. Koel (1963)). *3 Kui ka eeldada, et üleloomuliku olendi varju või hääle põhjuseks on vaid möödalendav lind vms, annab fakt meeltega kogetu konkreetsesse folkloorsesse kanalisse suunamisest kinnitust traditsiooni toimejõust.

Moodne psühholoogia toonitab taju suhtelisust: inimese silm ei ole fotoaparaat. Kipume asju nägema mitte sellistena, nagu nad on, vaid sellistena, nagu me ise oleme, s.t võtame informatsiooni vastu sellisena, nagu me oleme valmis teda vastu võtma. Teadvus aktualiseerib ajus vajalikud pildid. Traditsionaalsetes kultuurides kasutab inimene selles kehtivaid väljendeid ja mõisteid, s.t asetab oma elamused traditsiooni referentsraamidesse, mis on otsekui peegel, mille kaudu, millelt tagasi peegeldudes maailm tähenduse omandab (Honko 1962: 95, 99).

Niisiis kuulub laste tapmine - vähemalt meie kultuuriruumis ja vähemalt ajaloolisel ajal - nähtuste hulka, mida ühiskond ja avalik arvamus taunis. Usundilised kujutelmad, normatiivse käitumise resonantsina toimivad normi sanktsioonid suulises traditsioonis on üldeetiliste väärtuste kontrolli vahendiks. $\underline{* 4}$

\section{Reflektsioonid tänapäeva}

19. sajandil leiavad Euroopa, aga ka USA ja Jaapani rahvastiku arengus aset suured muudatused, mille tunnuslikud jooned on süvendatumal kujul iseloomulikud ka tänapäevale. Sündivus ja suremus vähenesid (Harris 1989: 108 jj). Üleminek perekonna reguleerimisele ( $\mathrm{nn}$ demograafiline revolutsioon) algas Prantsusmaal, kus juba 18. sajandil hakkas sündimus langema. Eriti märgatav oli langus pärast Suurt Prantsuse revolutsiooni. Veidi hilisemast ajast on täheldatav sündivuse langus Rootsis, Soomes, Inglismaal-Walesis ja Saksamaal. Ka Eestis toimus samal ajal üleminek perekonna planeerimisele (Palli 1997: 88-89) Samal ajal muutus laste kasvatamine kallimaks: laste töötamist reguleerivad seadused ja üldine koolikohustus pikendas perioodi, mille jooksul laps sõltus materiaalselt vanematest ja mille jooksul kestsid vanemate kohustused laste ees (Harris 1989: 108 jj). Ka Eestis leidsid 19. sajandi viimasel veerandil aset muutused demograafilises käitumises, mida iseloomustasid vähene sündivus, naiste madal viljakus, abielude ebapüsivus ja suur lahutumus. Kiirelt kasvas vabaabielude ja külastusabielude hulk (Palli 1997: 78). Käitumismustreid laste suhtes, mis olid omased agraarsele külaühiskonnale ja mida ajendasid lisaks eetilistele majanduslikud ja traditsioonist tingitud nõudmised (laps tööjõu allikana ja traditsiooni järjepidevuse tagajana), 
sanktsioneeriti valdavalt kogukonna siseselt. Nüüd, traditsionaalse ühiskonna struktuuri lagunedes, muutub keskseks riigipoolne kontroll. Kaasaja Euroopa ühiskond on laste tapmist sotsiaalse probleemina hakanud tõsisemalt teadvustama alates 18. ja 19. sajandist (O'Connor 1991: 29; Weeks 1981), kuigi üksikuid samme ebaseaduslike laste kaitseks astuti ka varem. 1623. aastal võeti Inglismaal ja 1690. aastal Shotimaal vastu seadus vallaslaste tapmise tõkestamiseks, mis oli valitsuse vastus "ebaseaduslike imikute sagedastele tapmistele" (O'Connor 1991: 29; Damme 1978: 12). See akt oli mitmeski mõttes ainulaadne, kuid 18. sajandil muutus laste tapmist käsitlev seadusandlus Euroopas üldiseks. 1803. aastal jõustus Inglismaal seadus, mis andis lootele juriidilise kaitse igas raseduse staadiumis. Kohtumenetluste arv jäi siiski suhteliselt väikeseks, mille põhjuseks on ilmselt avaliku arvamuse leige suhtumine, ja paljud kuriteod ei jõudnud avalikkuse ette. Seadusi tõhustati ja täpsustati aga jätkuvalt. 1861. aastal jõustunud seadus keelas Inglismaal abordi ja imikute hülgamise ning kaitseta jätmise (O'Connor 1991: 29-30).

Käesoleval sajandil kujundavad suhtumist abordisse ja seega ka vastavat seadusandlust jätkuvad rõhuasetuste ümberpaiknemised ühiskonnas. Üha enam sekkub igapäevaellu teadus.

Teaduse edusammud aitavad lahendada paljusid seni lahendamatuina tundunud probleeme, samal ajal toovad kaasa uusi ja kuumi eetilisi, sh bioeetika valdkonda kuuluvaid teemasid. Inimkatsed, sh inimese kloonimine jne on uute sõlmküsimustena astunud abordiprobleemi kõrvale. Viimase aktuaalsus pole ometi kahanenud. Laste tapmise vormide mitmekesisus on aga suurem. 1997. aasta juulis avaldatud ÜRO rapordis, mis käsitleb soolist diskrimineerimist, on abortide ja vastsündinud laste hülgamise kõrval muuseas kõne all ka kaudne laste tapmine: paljudes maades minnakse haige lapsega arsti juurde ainult siis, kui on tegemist poisslapsega (vt "Postimees" 24. juuli 1997). On selge, et nii nagu imiku tapmise ja kahe-kolmeaastase väikelapse tapmise vahel pole kvalitatiivset erinevust, ei saa ka abordi ja lapsetapmise vahel ei bioloogilises, saati siis eetilises plaanis kvalitatiivset erinevust näha. Võib tuua näiteid, millest ilmneb, et sageli ei saa lapse tapmist abordist selgelt eristada. Amazonase jõgikonnas elavate yanoamade juures kutsutakse kuuendal või seitsmendal raseduskuul esile kunstlik sünnitus, mille järel loode - kui ta annab elumärke - tapetakse (Harris 1989: 114).

Abordi võimalused on tänapäeva tehnilise taseme juures suurenenud. Nii nagu sünnist on saanud meditsiiniliselt suunatud kliiniline protsess ilma tõsiste mentaalsete protektsioonideta, valitseb sarnane suhtumine ka abordi suhtes. Enamikul juhtudel pole abort meditsiinile enam probleemiks. Sellega ei saa aga väita, nagu kaoks sellega ka eetiline probleem. Naise õigus otsustada raseduse üle on teravas konfliktis loote õigusega saada inimeseks. Abordiprobleem on niisiis igipõlise lastetapu ilmingu kaasaegne ekvivalent: kui arhailises ühiskonnas ei käsitatud vastsündinut isikuna, st tema tapmisele leiti juriidiline õigustus, siis tänapäev on jurisdiktsiooni pädevust piiranud tema nihutamisega inimarengu loote staadiumisse.

Varieeruv suhtumine laste tapmisse on kaasajal üha enam taandatav ambivalentsele suhtumisele kultuuri universaalkategooriatesse, sh surnute leinamisse ja surmasse üldse. Kaasaja ühiskonnas ilmneb tendents surelikkust dekonstrueerida ja patologiseerida: surmast on saanud haigus, mida on võimalik ravida. Sellega seonduv tendents - varasema surma kollektiivse määratletuse asemel isiklik tasand tänapäeval - pole siiski absoluutne. Kui ka kohati ilmneb surma võõrutatus tabude sfäärist, ei õnnestu teda siiski kultuurilise, sotsiaalse fenomeni staatusest täielikult vabastada. Isiklikus kokkupuutes surma või surijaga selgub tavaliselt, et kultuuri universaalsed kategooriad ei allu nii kergesti muudatustele. Selles ilmnebki ambivalentsus suhtumises surmasse: üheaegselt eksisteerivad teadvuses surma patoloogiline ja kultuuriline definitsioon (vt Magnusson 1996). 
Tänapäeva läänelikus ühiskonnas peetakse sünnitamisegi puhul normaalseks meditsiinilist mudelit ja sünnitajat vaadeldakse kui patsienti. Rasedus on haigusseisund, millele pöörab tähelepanu meditsiin (Kitzinger 1982: 198; Cormack 1982: 17).

Niisiis on sünd ja surm osaliselt vabastatud ühiskondlikust kontrollist, meditsiini valdkonda siirdumise tagajärjel on nad asetatud isikliku elu sfääri. Nagu surmast on väidetavasti saanud isiklik asi, on isiklikuks, s.t vabalt valitavaks muutunud ka suhtumine sünnisse, ühtlasi loote tapmisse. Konflikt jääb siiski õhku, sest inimesel on kalduvus otsida isiklikele otsustustele kinnitust kultuurist. Tekkinud on aga absurdne situatsioon, kus kultuur sisendab oma mõju puudumist. Tekkinud konflikti maandatakse umbisikulise loosunglikkusega, avalikule arvamusele apelleerimisega. (Suhtumises abordisse on avaliku arvamuse küsitlustes poolt- ja vastuhääled tavaliselt üpris tasakaalus.) Pluralistliku ühiskonna tunnusjooneks on konflikti tasandamine indiviidi ja ühiskonna vahel, st käitumisjuhiseks võetakse küll teiste inimeste eeskujust dikteeritu, kuid valiku olemasolu võimaldab eelistada endale sobivaimaks peetavat varianti.

Eetika seisukohast jagunevad tänapäeval vaated abordiküsimusele laias laastus kolmeks: 1) konservatiivne - abort on loote mistahes staadiumis meditsiiniliste vastunäidustuste puudumisel keelatud, 2) liberaalne - samadest eeldustest lähtudes teatud tingimustel lubatud, 3) feministlik - potentsiaalse sünnitaja vaba tahe. Konservatiivse lahenduse positiivse argumendina väidetakse, et loode on süütu inimolend, negatiivse argumendina aga seda, et liberaalist oponendil ei õnnestu seada inimolendi ja mitte-inimolendi piiri ühessegi viljastatud munaraku ja vastsündinu vahelisse arengujärku. Liberaalidest teoreetikute argumendid on teistsugused. Nad arvavad, et oma isikuõigused (moral rights) omandab inimorganism sünnimomendist. Eristatakse inimolendit (human being) ja isikut (person). Esimesel juhul on tegemist puhtbioloogilise liigitamisega homo sapiensi klassi, teisel juhul on organismil õigus olla koheldud kooskõlas moraalinõuetega, mis kehtivad enamusele ühiskonna liikmetest. Liberaal väidab, et loode ei tule inimolendina arvesse, kuna tal puudub iseseisva mõtlemise ja tegutsemise võime, st mingis loote staadiumis sündinuna ei jääks ta ellu. Selline kontseptsioon seab inimolendi ette tingimuse: õiguste omandamise väärimist tuleb tõestada eduka füüsilise ning vaimse arenguga, mis viib tema õigusteta olendite klassist isikute klassi. Niisiis pole selle seisukoha järgi mitte igaühel õigust olla isik (Parve 1995: 132-144; Laasberg 1996: 2412). Nii nagu traditsionaalsetes kultuurides sõltus laste tapmise õiguspärasus konventsioonidest ja reeglitest, millist last tohib tappa (vigane, hambaga sündinud jne), millist mitte, sõltub ta ka tänapäeva tsiviliseeritud ühiskonnas: kuulutades loote mitteisikuks, pole tema tapmine kvalifitseeritud mõrvana. Probleem oleks seega justkui puhtjuriidiline. Sarnane on näiteks suhtumine eutanaasiasse. Kui küsimusse tõuseb juriidilise ja humaanse vahekord, siis kaldutakse tavaliselt esimese poole, sest "humaanne" on väga suhteline mõiste, mida on raske defineerida. Kuid ka juriidlistes otsustustes jääb inimene sageli hätta, kuna teatud olukordade lahendamiseks seadusi pole ja ei saagi olla. Kui ka teatud (ekstremaalsetes) olukordades ei valmista kehtiv seadusandlus otsuse langetamisel raskusi, tekivad need ometi piirsituatsioonides. Toodagu siinkohal üks näide: Mõned aastad tagasi sündis Chicagos ränkade sünnikahjustustega laps. Arst seletas vanematele, et lapse elu võib päästa operatsiooniga, mis ei kõrvalda küll viga, aga võimaldaks lapsel teatud aja elada, vastasel juhul sureks ta ruttu. Sellest võimalusest vanemad aga loobusid, mispeale määrati lapsele riigi poolt eestkostja. Lapsele tehti mitmeid operatsioone, ta kannatas kohutavalt, kuid vanemate proteste ei võetud kuulda. Kord tuli lapse isa haigla intensiivosakonda, võttis taskust revolvri, rebis lapsel hingamisaparaadi ära, võttis nuttes poja kätele, laetud revolver suunatud põetajatele ja arstidele. Kui laps oli ta kätel surnud, kallistas ta teda nuuksudes. Loomulikult järgnes süüdistus tahtlikus tapmises. Mees mõisteti siiski õigeks kõigis süüdistuspunktides, v.a ebaseaduslikus relva omamises (Jonas 1993: 66 jj). 
Filosoof Hans Jonas esitab kaks lapsevanema vastutuse liiki lapse ees, positiivse ja negatiivse: positiivne hõlmab kohustuste täitmist, mis tagavad lapse edasielamise; negatiivne kõlab aga: kui kaugele me tohime minna, nõudes sigitatud lapselt elamist? Samas möönab ta, et väga raske on otsustada piiri üle, kust alates lapse elu on veel "elamisväärne" või pole enam "elamisväärne" (Jonas 1993: 73-74).

Lapse elu üle otsustamise kontekstis on oluline naise roll ühiskonnas. Patriarhaalse talupojaühiskonnaga võrreldes on tänapäeva naise õiguslik seisund muutumas. Meenutame veelkord Marjatta ja Väinämöise lugu, Taamari ja Juuda lugu või ka tapetud lapsega seotud muistenditraditsioonis esinevat tendentsi teha vastutajaks üksnes lapse ema. Tänapäeva ühiskonnas ei piirdu naise roll enam ainult laste ja koduga, tendents, mis on viimas selleni, et esitatakse küsimus naise rollist perekonnas üldse. Traditsiooniline ema-lapse side, mis baseerub emaduse bioloogilisel olemusel (eelnevalt nägime, et isadust mõistetakse traditsionaalses ühiskonnas pigem sotsiaalse nähtena), rahuldab modernset naiseksolemise mustrit üha vähem.

Feministlik probleem, miks on alati süüdi emad ja mitte isad, oli teemaks skandaalsele loole, nn "Nanny-protsessile", mis mõni aeg tagasi leidis aset Ameerikas Massachusettsis ning pani kihama sealse meedia. Dr Deborah Eappen ning tema abikaasa on kvalifitseeritud arstid. Nende kaheksakuune laps jäeti noore (19-a) inglise lapsehoidja Louise Woodwardiga üksi. Vaene Louise oli kena, aga pisut ebakompetentne (umbes nii väljenduti ajakirjanduses) ning laps suri. Algas kohtuprotsess, mida valgustati massimeedias põhjalikult. Dr Eappen, surnud lapse ema, jäi avalikkuse silmis süüdlaseks: ta töötas kolm päeva nädalas arstina ega olnud kogu aeg oma lapse juures. Teda nimetati rongaemaks ning üldistus, mis võimendus ajakirjanduses, kõlas: töötavad emad on koletised, sest nad ei istu kogu aeg kodus. Feministlike aktivistide poolt leidis selline reaktsioon terava hukkamõistu. Protsessile heideti ette, et seal vaieldakse vaid selle üle, kumb naine on süüdi, meest aga ei süüdista keegi (vt näiteks Mann Jong 1997).

Niisiis pole ühiskonna hoiak ka sellistes põhimõttelistes küsimustes, nagu seda on laste kasvatamine (ja mis patriarhaalses agraarühiskonnas ei tule üldse arutuse alla), sugugi ühene.

Pluralistliku ühiskonna valikute ja otsustuste vabadus eristab teda traditsionaalsest ühiskonnast, kuid seda vaid teatud piirini. Avalik arvamus, kajastugu ta siis muistendites, tänapäevastes avaliku arvamuse küsitlustes või aeg-ajalt üldsust raputavates skandaalides, ei tegele üldjuhul piirsituatsioonidega, olles seega tüüpseisukohtade kajastajaks. Kõrvutan siinkohal paar teksti.

Umbes 100 aastat tagasi elanud Seli vallas Vihaksi külas tüdruk Eerikesauna Leenu. Ta tapnud oma lapse ära ja matnud Jaaniaia väravale suure kivi alla ja ise läinud kõrtsi tantsima. Selle kivi lähedusest möödakäijad eksisid tihti ära, nähes oma ees mäge, linna ehk muud

(E, StK 3, 112 (6) < Tõstamaa khk - A. Laan (1921)).

Võrdluseks analoogiline usundiline jutt Ida-Rootsist:

Palju-palju aastaid tagasi tappis üks tüdruk vastsündinu ja mattis koplisse. Naabruses oli sel õhtul tantsupidu, kuhu tüdruk siis ruttas...

(Pentikäinen 1968: 143-144). 
Ei hakka seda pikemalt refereerima, olgu vaid öeldud, et ka selles loos sai tapetud lapsest paiga kaitsehaldjas, kuid tantsupeo nimetamine näib olevat olulisem.

Muistenditekstide kõrvale tooksin loo tänapäeva massimeediast. Mõni aeg tagasi lõi Ameerika ajakirjanduses laineid lugu, kuidas üks teismeline tüdruk tappis kooli lõpupeol WC-s lapse. Õpilane pakkis vastsündinu kilekotti ja jättis ta WC-sse. Siis läks ta tagasi tantsusaali, sest tahtis paluda diskorit mängida oma sõbrale üks lugu. Beebi leiti hiljem surnult (Schwelien 1997). Ilma tantsuloota poleks uudis ilmselt erilist kõlapinda leidnud.

Kõmulugude paralleelid varasemate muistenditekstidega on ilmsed, moraalitust normi rikkumisel rõhutatakse sama skeemi järgi nii agraarses kui modernses linnalikus ühiskonnas. Samas on ühiskonna loodud konventsioonid ühesuguse mõjuga nii kiviajal, agraarses talupojakogukonnas kui modernses läänelikus ühiskonnas: need paar viimasel ajal massimeediat raputanud sündmust poleks mingit laiemat kõlapinda leidnud, kui tegemist oleks olnud abordi ja mitte laste tapmisega (Vrd primitiivsete kultuuride lapse ühiskonda inkorporeerimise konventsioonidega).

Normist hälbimisele reageerib aga ühiskond ühtmoodi: karistus järgneb ühiskonna poolt tunnustatud liikme tapmisele nii primitiivses ühiskonnas, agraarses kui ka kaasaegses linnaühiskonnas. Vahe on ehk selles, et kaasaegses ühiskonnas, kus erisuunalisele suhtumisele abordi/lapsetapmise lubatavusse ning teistessegi eetilist otsustust nõudvatesse küsimustesse lisandub ka ühiskonna sekulariseerumine, mis loob olukorra, kus skeem normide rikkumisele järgnevast üleloomulikust ning paratamatust karistusest ei rakendu.

\section{Lõpetuseks}

Muutustega, mis on aset leidnud traditsionaalse agraarühiskonna asendumisel industriaalühiskonnaga, on muutunud ka lastetapmise/abordi motiivid. Agraarsele külaühiskonnale omaseid käitumismustreid asendavad uued, individualiseerumisest ja võõrandumisest lähtuvad. Majanduslike põhjuste ambivalentne mõju (majanduslikud mehhanismid põhjendasid traditsionaalses kogukonnas nii laste tapmist kui lasterikaste perekondade vajalikkust) on asendunud ühesuunalisega, mille puhul järeltuleva põlvkonna vajalikkus üheselt ei teadvustu. Samas pole ühiskonna hinnang vallaslastele enam selline nagu varem. Olukord, kus "tõendit, et ollakse sündinud seaduslikust abielust, nõuti igal sammul" (Salupere 1997: 18), on muutunud. S.t teisenenud on moraalsed perspektiivid.

Ühiskonna üheks suurimaks suhtumise kujundajaks on tänapäeval avalik arvamus. Samas on ta ka taganemistee. Traditsioon kujundab teda vaid osaliselt. Niisiis tekivad uued reeglid, mis suuresti ei kattu traditsioonist tuntutega. Tekkinud alternatiivid võimaldavad individuaalse otsustamise vastupidi traditsionaalses kultuuris kehtivale käitumismustrile. Tänapäeva Uue Laine harjal navigeerivad kõikvõimalikud end uueks nimetavad nähtused, sh uus moraal, kuigi jääb küsitavaks, kas iga nähtus, mis end mingi varasema nähtuse uueks vormiks nimetab, omab geneetilist seost selle varasemaga.

Ühiskonna normaalse toimimise tagab seal kehtivate väärtuste, normide ja normi sanktsioonide koostoime. Traditsionaalses ühiskonnas on üheks kehtivaks väärtuseks edasikestmine järeltuleva põlvkonna läbi, selle normiks laste tapmise keeld ning normi sanktsiooniks tapetud laps üleloomuliku olendina. Võiksime ju esitada küsimuse - mis tänapäeva sekulaarses ühiskonnas toimib sanktsioonina, milline on üleloomuliku tapetud lapse kaasaegne ekvivalent? - kuid enne tuleb leida vastus ühele teisele küsimusele ja nimelt: millise sõna või mõtte võime kirjutada modernse ühiskonna väärtuse lahtrisse. 


\section{Kirjandus}

Damme, C. 1978. Infanticide. Medical History, Vol. 22, pp. 1-24.

Devereux, George. 1967. A Typological Study of Abortion in 350 Primitive, Ancient, and PreIndustrial Societes. Abortion in America. (Ed by H. Rosen). Boston, pp. 95-152.

Encyclopaedia of Superstitions, Folklore, and the Occult Sciences of the World. A Comprehensive Library of Human Belief and Practice in the Mysteries of Life through more than six thousand Years of Experience and Progress 1971. Vol. 1. (Ed by Daniels, C. L.; C. M. Stevans). Detroit. Gross, Toomas 1997. Uued paljunemistehnoloogiad ja emaduse dekonstruktsioon. Akadeemia, nr 10, 2149-2169.

Harris, Marvin 1989. Kulturanthropologie: Ein Lehrbuch. Frankfurt am Main.

Hofmann, Hans H. 1970. Acta, ein Vergraben gefundenes, ermordetes Kindt betreffend, Anno 1746. Eine soziokulturelle und rechtshistorische Studie aus dem Leben der Unterständischen. Volkskultur und Geschichte (Hsg. von D. Harmening, G. Lutz, B. Schemmel, E. Wimmer) Berlin. Holma, H., Barthold, V. 1933. Muhamed ja islam. Tartu. Honko, Lauri 1962. Geisterglaube in Ingermanland I. FFC No. 185. Helsinki.

Jonas, Hans 1993. Dem bösen Ende näher. (Gespräche über das Verhältnis des Menschen zur Natur). Frankfurt am Main.

Jürgenson, Aivar 1997. Eksitajast ja eksimisest eesti usundis. Akadeemia, nr 4, 710-731.

Kitzinger, S. 1982. The Social Context of Birth: Some Comparisons between Childbirth in Jamaica and Britain. Ethnography of Fertility and Birth. (Ed by Carol P. Mac Cormack) New York, pp. 181203.

Laasberg, Margo 1996. Rasked valikud. Arvustus: Loone, Eero (toim.) Mõistlike valikute õigustamise filosoofilised eeldused. Tartu 1995) - Akadeemia, nr 11, 2405-2412.

Mac Cormack, Carol, P. 1982. Biological, Cultural and Social Adaptation in Human Fertility and Birth: A Synthesis. Ethnography of Fertility and Birth. (Ed by Carol P. Mac Cormack) New York, pp. 1-23.

Magnusson, Finnur 1996. Narratives of Modern Dying. Looking for Authentic Death. Pro Ethnologia, No. 4, pp. 81-88.

Mann Jong, Erica 1997. Monster-Mütter. Die Zeit, No. 50, 5. Dec., S. 61.

Mead, Margaret 1947. Adolescence in Primitive and in Modern Society. Readings in Social

Psychology. (Ed by M. Newcomb; L. Hartley). New York, pp. 6-14.

O'Connor, Anne 1991. Child Murderess and Dead Child Traditions. A Comparative Study. FFC, no 249. Helsinki.

Palli, Heldur 1997. Jooni Eesti rahvastiku demograafilise käitumise muutumisest. Acta Historica

Tallinnensia, nr 1, 78-91.

Parve, Valdar 1995. Abordiprobleem moraaliteooriate konkurentsis. Mõistlike valikute õigustamise filosoofilised eeldused. (Koost Eero Loone) Tartu, 131-145.

Pentikäinen, Juha 1968. The Nordic Dead-Child Tradition. Nordic Dead-Child Beings. FFC, no 202. Helsinki.

Puhvel, Jaan 1996. Võrdlev mütoloogia. Tartu.

Salupere, Malle 1997. Kaks vestlusseeriat. Postimees 28.04.1997, 1k. 18.

Schwelien, Michael 1997. Die Mea-culpa-Jahre. Die Zeit, no 52, 19. 12. 97, S. 40.

Weeks, J. 1981. Sex, Politics and Society. The Regulation of Sexuality since 1800. London, New York. 
1 Mõnes tekstis ilmneb asenduse vajadus leebel kujul: laps teatab, et vabaneb needusest pärast ema surma, kuid ei nõua kättemaksu, s.t annab mõista, et ootab ära ema loomuliku surma.

2 Nagu märgib oma artiklis Toomas Gross, on antropoloogiateaduses ema-lapse sideme olulisust peetud inimliigile üldomaseks (Gross 1997: 2151).

3 Värdjaks nimetati tüdruku surnud lapsi (nt KKI 8, 115/6 (228) < Kuusalu - H. Ernesaks (1948)

4 Kuigi laste tapmist ja ühiskonna hinnangut sellele peegeldavad usundilised kujutelmad, mida võib vaadelda ajalooallikatena, tuleks teema edasise käsitlemise huvides pöörduda ka kirjalike allikate, näiteks kohtutoimikute poole. On selge, et keskajal oli õigusteta ja varanduslikult madalaid positsioone hõivanud lihtrahvas suuresti anonüümne. Inimene, kes pärines massidest, sattus tähelepanu orbiiti enamasti vaid konfliktsete situatsioonide korral, siis, kui ta oli ära teeninud mingi karistuse, mida reglementeeris riik oma institutsioonidega. Üheks selliseks, kuriteona

kvalifitseeritud sündmuseks, oli kindlasti laste tapmine (vt Hofmann 1970). 